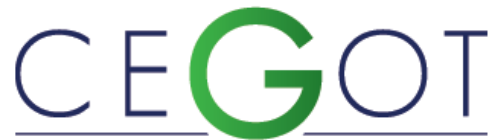

Centro de Estudos de Geografia e Ordenamento do Território
PINHO, GISELLE

PPGATC UNICAMP

Rod. Augusto Montenegro, 5955, Cond. Cidade Jardim, Rua Margarida 1B-51,

66635110, Belém, Brasil

fpgiselle@gmail.com

MONTEIRO, EVANDRO

Faculdade de Engenharia Civil Arquitetura e Urbanismo da

UNICAMP / PPGATC UNICAMP

13083-889, Caixa Postal: 6143, Campinas (SP), Brasil

evandrozig@fec.unicamp.br

PINA, SílVIA

Faculdade de Engenharia Civil Arquitetura e Urbanismo da

UNICAMP / PPGATC UNICAMP

13083-889, Caixa Postal: 6143, Campinas (SP), Brasil

smikami@fec.unicamp.br

\title{
Urbanidade na floresta: a apropriação do rio pelas morfologias de ocupação da
} Amazônia

Urbanity in the forest: appropriation of the river by the occupation morphologies of the Amazon

Referência: Pinho, Giselle; Monteiro, Evandro; Pina, Sílvia (2019). Urbanidade na floresta: a apropriação do rio pelas morfologias de ocupação da Amazônia. Revista de Geografia e Ordenamento do Território (GOT), n. ${ }^{\circ} 17$ (junho). Centro de Estudos de Geografia e Ordenamento do Território, p. 201-227, dx.doi.org/10.17127/got/2019.17.009

\section{RESUMO}

Neste artigo, a análise determinou como os padrões atuais de assentamentos de reforma agrária evoluíram morfologicamente comparados com outros três períodos de colonização. Os planos analisados são aqueles implementados na Amazônia Oriental em quatro períodos: Pombalino, Borracha, Militar e Contemporâneo. Um conjunto de sete características morfológicas foi analisado, a saber: sistema viário, praças, eixo das vias, relação entre ruas e cursos d'água, parcelamentos, padrões de fachada e afastamentos. Somado à análise morfológica, também foi analisada a correlação entre as funções dos cursos d'água e sua relevância para os planos de colonização/assentamento. $O$ estudo conclui que os atuais planos de assentamento desenvolveram morfologias mais diversas e complexas em relação aos antigos planos de colonização. Entretanto, permanecem pouco exploradas formas e mecanismos que proponham a efetiva apropriação do rio pela estrutura morfológica dos assentamentos.

Palavras-chave: Morfologia Urbana, Urbanidade, Amazônia Oriental, Planos de Colonização, Recursos Hídricos.

\section{ABSTRACT}

In this paper, the applied morphological analysis determined how current agrarian reform settlements patterns evolved compared to during three other colonization periods. The 
analyzed plans are those implemented in the Eastern Amazon in four periods: Pombalino, Borracha, Militar, and Contemporary. The analysis was composed of seven morphological traits, namely: road network, plazas, road axis, the relation between roads and watercourses, land subdivisions, façade patterns, and setbacks. In addition to the morphological analysis, an analysis of the correlation between the functions of the watercourses and their relevance to the colonization/settlement plans also took place. In conclusion, compared to those old colonization plans, the current settlement projects have developed a more diverse and complex morphology. However, it remains little explored how the morphological structure of settlements can effectively incorporate the rivers through proper methods and mechanisms.

Keywords: Urban Morphology; Urbanity; Eastern Amazon; Colonization Plans; Water Resourcers.

\section{Os planos de colonização e assentamento}

O Instituto de Colonização e Reforma Agrária (INCRA) atua na Amazônia com planos de ocupação desde a década de 1970, implantando assentamentos e intervindo para solucionar disputas por terra entre grandes fazendeiros e os trabalhadores rurais sem terra. Atualmente o INCRA promove diversas modalidades de assentamento, diferenciadas basicamente pelo seu quinhão econômico, por exemplo, a modalidade Projeto de Assentamento Federal (PA) é orientada para "implementação dos sistemas de vivência e produção sustentáveis", enquanto que o Projeto de Assentamento Agroextrativista (PAE) "é destinado à exploração de área dotadas de riquezas extrativas" (INCRA, 2018).

Atualmente a implantação de um assentamento é um processo de três anos que se inicia com a publicação de uma portaria, onde constam os dados do imóvel, a capacidade estimada de famílias, o nome do projeto de assentamento e os próximos passos que serão dados para sua implantação, que vai desde ações políticas sociais como a execução do cadastro das famílias beneficiárias e oferecimento de cursos de qualificação do Programa Nacional de Acesso ao Ensino Técnico e Emprego - PRONATEC; a implantação da infraestrutura básica (soluções de luz, água e moradia), elaboração do anteprojeto de parcelamento, recuperação e implantação de estradas e demarcação das parcelas. Nesse processo também são oferecidas propostas de apoio à produção e realizada a regularização fundiária (INCRA, 2018).

Cada assentamento é, portanto, um projeto individualizado com pré-requisitos comuns a todas as modalidades: unidades produtivas (lotes rurais) e de moradia, áreas comunitárias e 
espaços para construção de igrejas, centros comunitários, sede de associações. Há de se ressaltar também a questão dos cursos d'água existentes na área de implantação, pois são previstos "locais de preservação ambiental cercados e protegidos" (INCRA 2018).

Cabe questionar, então, o quanto as modalidades atuais de assentamento de reforma agrária evoluíram morfologicamente, em especial quanto à questão da apropriação dos rios, em relação à outros planos de assentamento e colonização, dando enfoque àqueles realizados em território amazônico, especialmente na Amazônia Oriental.

Este artigo tem por objetivo analisar as características morfológicas de planos de colonização da Amazônia em quatro momentos distintos (FIG.1): A) os planos do período pombalino; B) os planos de colonização da ferrovia Belém-Bragança no período do Boom da Borracha; C) os planos desenvolvidos no período militar para a colonização da Transamazônica; e D) os planos de Assentamentos Rurais do INCRA desenvolvidos a partir de 1990, foram selecionadas dois PAs no município de Moju para a análise, o PA Olho D'água e o PA Boa Esperança.

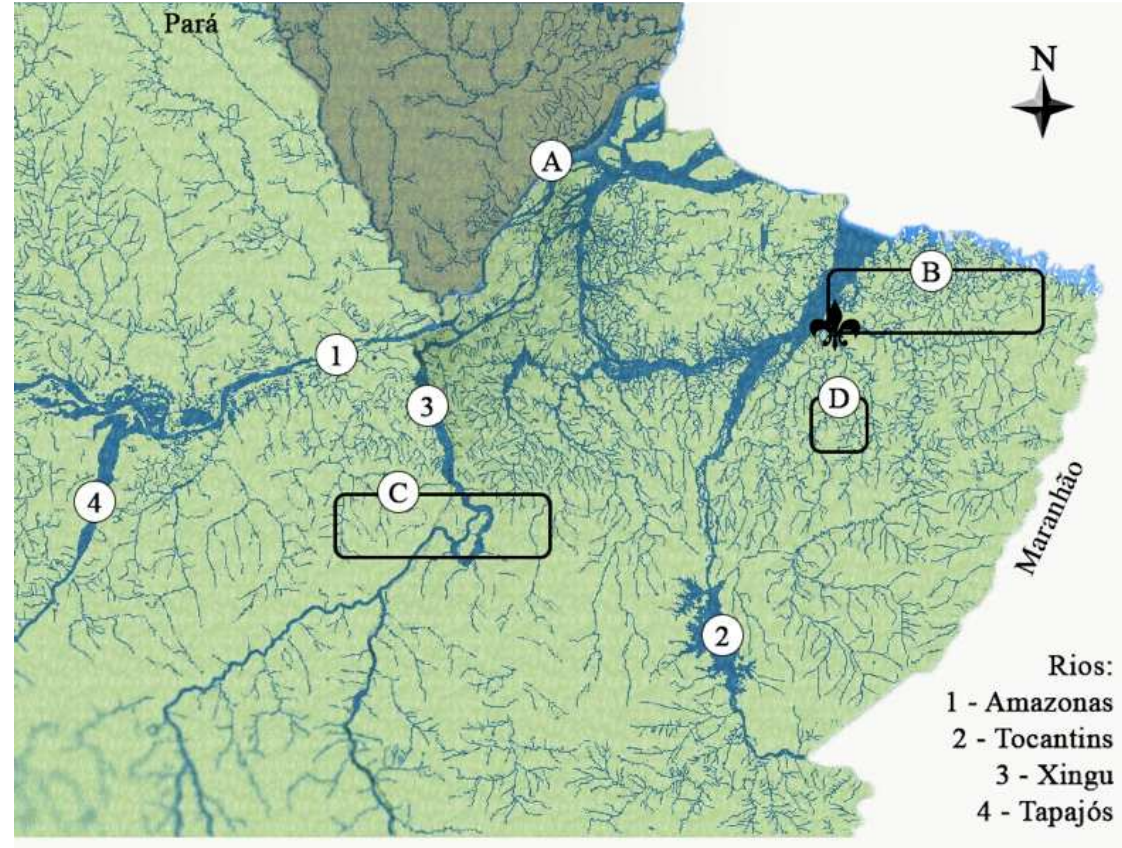

Legenda

Localização dos Planos de Colonização:

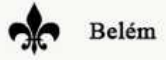
A) no Periodo Pombalino
B) no Período da Borracha (1890-1900)
C) no Período Militar (1970-1974)
D) no Período Contemporâneo (1990-)

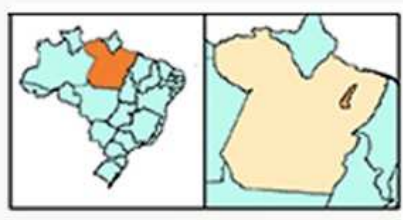

Figura 1 - Estudo morfológico de Mazagão realizado por TEIXEIRA (2012) Elaboração: Autora 
Os planos analisados para os períodos pombalino, da borracha e militar foram selecionados a partir de extensiva pesquisa documental, os planos referentes aos atuais assentamentos do INCRA foram desenvolvidos empiricamente a partir de dados coletados em campo (visitas realizadas em julho de 2017) e imagens de satélite das localidades.

\section{A metodologia para a análise morfológica}

Optou-se por uma abordagem morfológica para se analisar os planos de colonização por essa disciplina, segundo Del Rio (1990, p. 86), ter sua importância fundamentada em

"[...] compreender a lógica de formação, evolução e transformação dos elementos urbanos e de suas inter-relações, a fim de possibilitar-nos a identificação de formas mais apropriadas, cultural e socialmente, para a intervenção na cidade existente e desenho de novas áreas."

Por ser um estudo realizado primordialmente sobre documentos históricos, a metodologia utilizada neste artigo se apoiou em preceitos/elementos da Escola Inglesa, também conhecida como Conzeniana, por esta estudar como os diferentes elementos se conjugam sobre o solo, ao reconhecer que a paisagem urbana é tripartida (WHITEHAND, 2013), e por ser um estudo de forte caráter histórico. Os estudos realizados por M. R. G. Conzen, em especial seu estudo sobre Alnwick realizado em 1960, serviram de base para criação da escola inglesa de morfologia. Segundo Samuels (2005) Conzen criticava a aplicação de modelos conceituais de planejamento, por estes não considerarem as diferenças nas bases socioeconômicas das cidades, ou seja, esses modelos negligenciavam a importância dos indícios históricos, de desenvolvimento e culturais na configuração dos assentamentos humanos. Oliveira e Monteiro (2014) também se referem a Conzen esclarecendo que para ele era necessário, primeiramente, compreender os aspectos históricos e morfológicos, entender os motivos e as características que levaram a escolha do local original de cada assentamento humano, antes de se proceder ao planejamento de novas áreas.

Ainda segundo Samuels (2005), Conzen preocupava-se em seus estudos com cinco pontos principais: 1) todas as edificações componentes de uma cidade; 2) como o ambiente construído muda - sendo esse elemento o mais enfatizado em seus estudos; 3 ) como certas partes desse ambiente construído mudam em diferentes velocidades; 4) como se dá a 
conservação de áreas urbanas; e 5) o papel do desenho urbano como ferramenta de exploração.

Portanto, a metodologia de Conzen (1960) aponta que a forma urbana pode ser definida como um arranjo topográfico da área construída, considerando todos os seus aspectos e contendo três elementos de estudo distintos:

I) as ruas e a sua organização em um sistema viário;

II) os lotes e a sua conformação em quadras; e

III) os edifícios em sua forma construída.

Conzen (1960) sugere um método de análise que compreende a observação em campo do ambiente construído, considerando as ruas (sistema viário), as quadras (considerando sua repartição em lotes), o uso e ocupação dos lotes (uso dos edifícios e número de pavimentos), sem desconsiderar que a análise da forma física também está vinculada ao contexto econômico e social.

Assim, ao se analisar os projetos de assentamento, considerou-se, por um lado, as questões socioeconômicas e políticas associadas à introdução dessas novas formas urbanas; e por outro, as características físicas dos diversos componentes do desenvolvimento urbano de cada projeto.

A análise morfológica considerou um conjunto de sete características, a saber: o tipo de traçado viário, a existência de praças e sua relação com o traçado, o eixo principal de organização do traçado viário, a relação entre o traçado e os cursos d'água, a forma de parcelamento das quadras, padrões de fachada e ocorrência de afastamentos.

Analisou-se primeiramente todas as características referentes ao traçado viário, ou seja, identificação das vias principais, das vias secundárias, do eixo principal de implantação e a configuração das vias em sistemas viários (se são lineares ou em grelha). Em seguida analisou-se se o sistema viário permitia a existência de quadras, como se dava o parcelamento dos lotes e se existiam padrões para a implantação das edificações, dando enfoque para a ocorrência ou não dos padrões de fachada e a exigência de afastamento dos 
limites dos lotes. Por último realizou-se a análise da relação entre a função dos cursos d'água ${ }^{1}$ e sua relevância para os planos de colonização/assentamento.

\section{A cidade de costas para o rio}

Como o primeiro período no qual foram efetuados esforços para se planejar os novos núcleos de colonização e mesmo reorganizar núcleos já existentes, o período pombalino possui dois marcos morfológicos importantes. O primeiro deles foi a Lei de 1755 conhecida como "Diretório", a qual estabeleceu um critério de densidade demográfica para a criação de vilas. Essa Lei estabelecia que as antigas missões religiosas seriam elevadas à categoria de "vila" caso possuíssem uma população mínima de 150 habitantes, do contrário seriam consideradas "lugares" (FLEXOR, 2010; BAENA, 1969). O segundo marco desse período foi o processo de homogeneização urbanística advindo dos planos que chegavam às colônias principalmente através de cartas, ou seja, instruções escritas poucas vezes acompanhadas de desenhos e que poderiam ser adaptadas segundo a situação de cada vila. Neste período recomendava-se que as vilas seguissem um plano ortogonal tendo como área central uma praça (cívica ou religiosa) onde seriam construídos os prédios públicos, todas as vias deveriam seguir padrões de regularidade, racionalidade e simetria, sendo necessariamente largas o suficiente para promover a "beleza" e a "boa perspectiva" que por sua vez advinha do padrão construtivo das fachadas dos edifícios (FLEXOR, 2010; DELSON, 1997).

De acordo com Teixeira (2012, p.159) "a cidade portuguesa setecentista é uma cidade regular, com uma estrutura de base geométrica, a maior parte das vezes ortogonal e planejada de forma global". Ainda segundo esse autor, uma ou duas praças eram os elementos estruturadores do traçado viário; principalmente quando duas praças ocorriam, uma vez que elas ocupavam porções distintas e normalmente diametralmente opostas no sítio escolhido, fazendo com que as vias principais que as conectavam fossem sempre estabelecidas no sentido Leste-Oeste. O traçado viário era concebido de uma grelha

\footnotetext{
${ }^{1}$ Ressalta-se que as funções relacionadas à subsistência da população como pesca e utilidade doméstica (onde se lavam roupas) são consideradas intermitentes a todos os planos e que as funções apresentadas no artigo estão relacionadas à questão morfológica de como os planos se apropriam dos cursos d'água.
} 
ortogonal conceitual, que por sua vez era então adaptada às especificidades locais como rios e elevações.

Observando-se a análise morfológica das cidades de Macapá (p. 62-66) e Mazagão (p.128129), efetuadas por Teixeira (2012), as adaptações das grelhas ortogonais conceituais foram ajustadas de forma a evitar os cursos d'água e as áreas alagadiças, privilegiando, portanto, as áreas mais altas de terra firme. Neste período, aos rios e igarapés era atribuída a função de via de circulação e transporte, porém essa função não era apropriada internamente pelos planos de colonização. As frentes de lotes sempre estavam voltadas para as áreas mais altas, as quais permitiam as perspectivas e as simetrias de fachada e, portanto, não se aplicavam afastamentos nas edificações (FIG. 2).

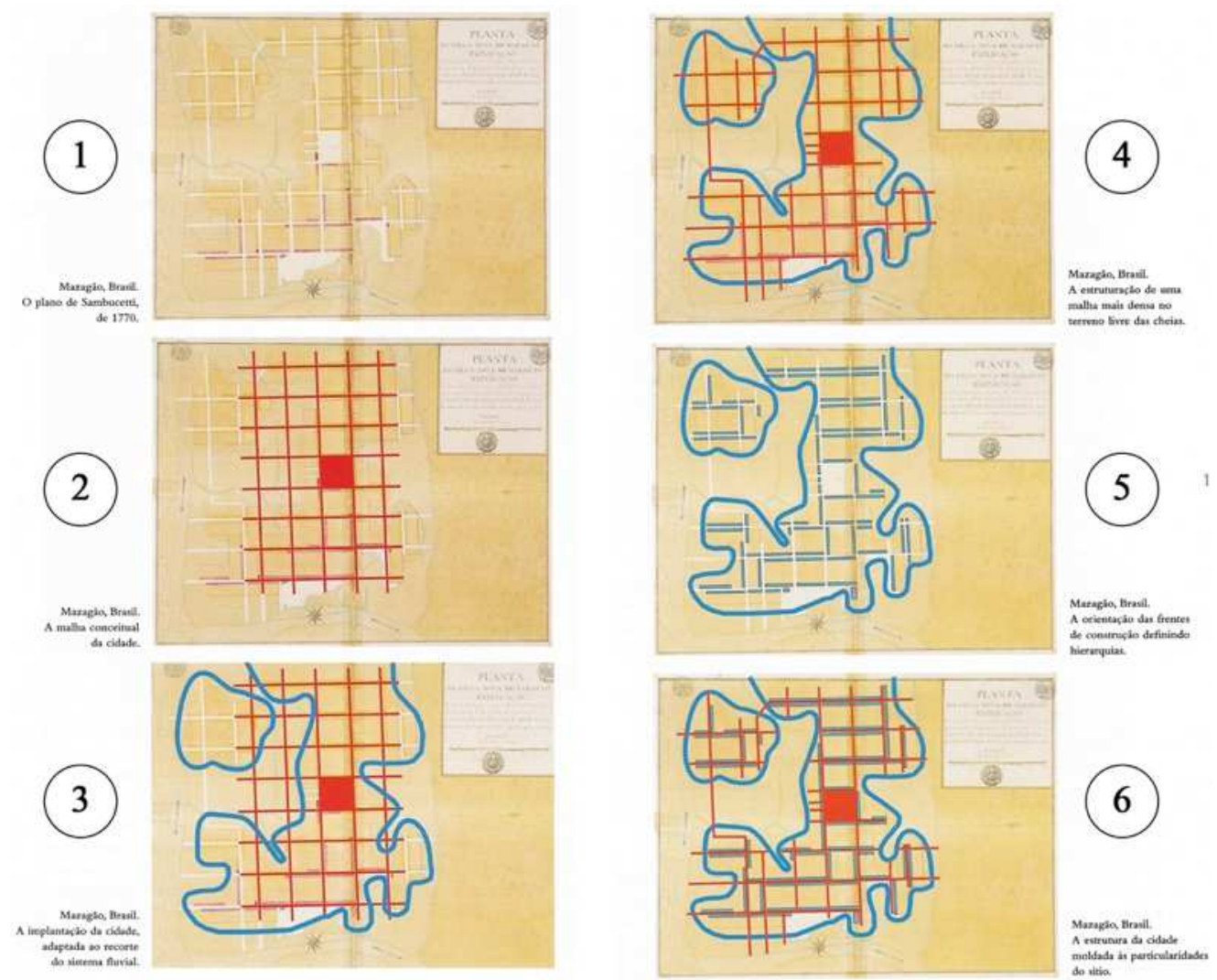

Figura 2 - Estudo morfológico de Mazagão realizado por TEIXEIRA (2012) Fonte: Adaptado de TEIXEIRA (2012)

O parcelamento dos lotes valorizavam com as fachadas principais os eixos viários no sentido Leste-Oeste, no sentido Norte-Sul ocorriam com mais frequência as fachadas laterais, reforçando quadras com uma ou duas frentes de lote dependendo do posicionamento das quadras em relação às áreas alagadiças. 
Resumidamente a morfologia nesse período consistia de traçado viário ortogonal no qual as praças eram importantes componentes de um traçado que valorizava o eixo viário Leste/Oeste ao mesmo tempo que evitava implantar frentes de lote voltados para os cursos d'água e áreas alagadas; o sistema viário permitia o surgimento de que quadras eram parceladas de forma a estabelecer duas fachadas principais, que por sua vez não se utilizavam de afastamentos e priorizavam um padrão de fachadas.

\section{O rio é rua (só que não)}

A cidade de Bragança foi fundada em 1634 com a nomenclatura de Vila de Souza do Caeté, pois situava-se a $16 \mathrm{Km}$ da foz do Rio Caeté, e era uma das poucas vilas que se situava fora das grandes redes fluviais de circulação nos rios Amazonas, Tapajós, Xingu e Tocantins. Essa vila foi fundada como um entreposto no caminho entre Belém e São Luiz na expectativa de substituir o perigoso caminho náutico por um caminho em terra firme. Para se chegar a Belém, saindo de Bragança, era necessário percorrer 25 léguas em seis ou oito dias em duas modalidades, por terra até a Vila de Ourém e daí até Belém seguia-se pelo Rio Guamá. Até 1875 essa região permaneceu vazia e as primeiras iniciativas de ocupá-la ocorreram como uma repercussão do ciclo da borracha ${ }^{2}$ através da implantação de uma estrada de ferro ligando Belém a Bragança.

A partir da metade da década de 1870, o governo estadual passou a investir em "núcleos" de colonização (iniciativa pública) e em "burgos agrícolas" (iniciativa privada), sendo que o auge das implantações ocorreu entre os anos de 1894 e 1914, principalmente nos governos de Lauro Sodré e Paes de Carvalho. Em sua maioria, esses núcleos eram voltados para a colonização com a introdução de imigrantes europeus (WEINSTEIN, 1993; PENTEADO, 1967).

\footnotetext{
2 A iniciativa de colonização possuía dois motivos principais ainda que aparentemente antagônicos: 1) reverter a retração de outras atividades produtivas e da comercialização de produtos advindos dessas atividades (DAOU, 2000); 2) fomentar os lucros de seringalistas e casas aviadoras, que supririam os seringueiros com produtos alimentícios nacionais pelos preços usuais dos gêneros importados (WEINSTEIN, 1993).
} 
A primeira colônia a ser implantada foi a de Benevides em 1875, subsequentemente foram implantadas as colônias do Apeú, Marapanim, Castanhal, Araripe, todas localizadas nas proximidades de Belém a leste. Em 1894 foi implantada a colônia de Benjamin Constant no extremo oposto, já próximo a Bragança; em seguida a porção central da região foi colonizada com os núcleos Jambu-Açú, Santa Rita, Granja América, Santa Rosa, Ferreira Pena, Anita Garibaldi, José de Alencar, Inhangapi e lanetama (PENTEADO, 1967).

Após essa fase inicial, outras colônias foram instaladas entre os núcleos de Jambu-Açú e Benjamin Constant, foram elas os núcleos Maracanã, Capanema, São Luíz e Anhangá, também foram instalados neste período o Instituto do Prata e o Aprendizado Agrícola. A figura a seguir (FIG. 3) demonstra como foi esse processo de ocupação, sempre seguindo o avanço da estrada de ferro Belém-Bragança, a qual demorou 25 anos para ser finalizada.

Cada núcleo de colonização era um projeto individualizado, composto de lotes rurais e de uma sede com lotes urbanos. Morfologicamente, os planos destes núcleos seguiram, em sua maioria, as linhas coloniais, com as suas vias principais orientadas no eixo Leste-Oeste, vias transversais eram abertas regularmente, em alguns casos existiam vias paralelas ao eixo principal, formando malhas em grelha, ortogonais e simétricas. A distribuição dos lotes rurais foi em sua maioria realizada de forma homogênea, obedecendo um tamanho padrão de 25 ha (250 m de frente $\times 1000 \mathrm{~m}$ de fundo). Essa distribuição dos lotes e organização viária, diferentemente do período colonial/pombalino, se utilizava até certo ponto da hidrografia local, pois diversos rios e igarapés constavam nos planos como via de circulação e transporte interno ao núcleo de colonização. No entanto, os lotes fortemente influenciados pelos igarapés e rios permaneciam vazios, enquanto os colonos davam preferência os lotes mais secos, ocupando com suas moradias as frentes de lote ao longo da via principal e de algumas transversais (FIG. 4). 


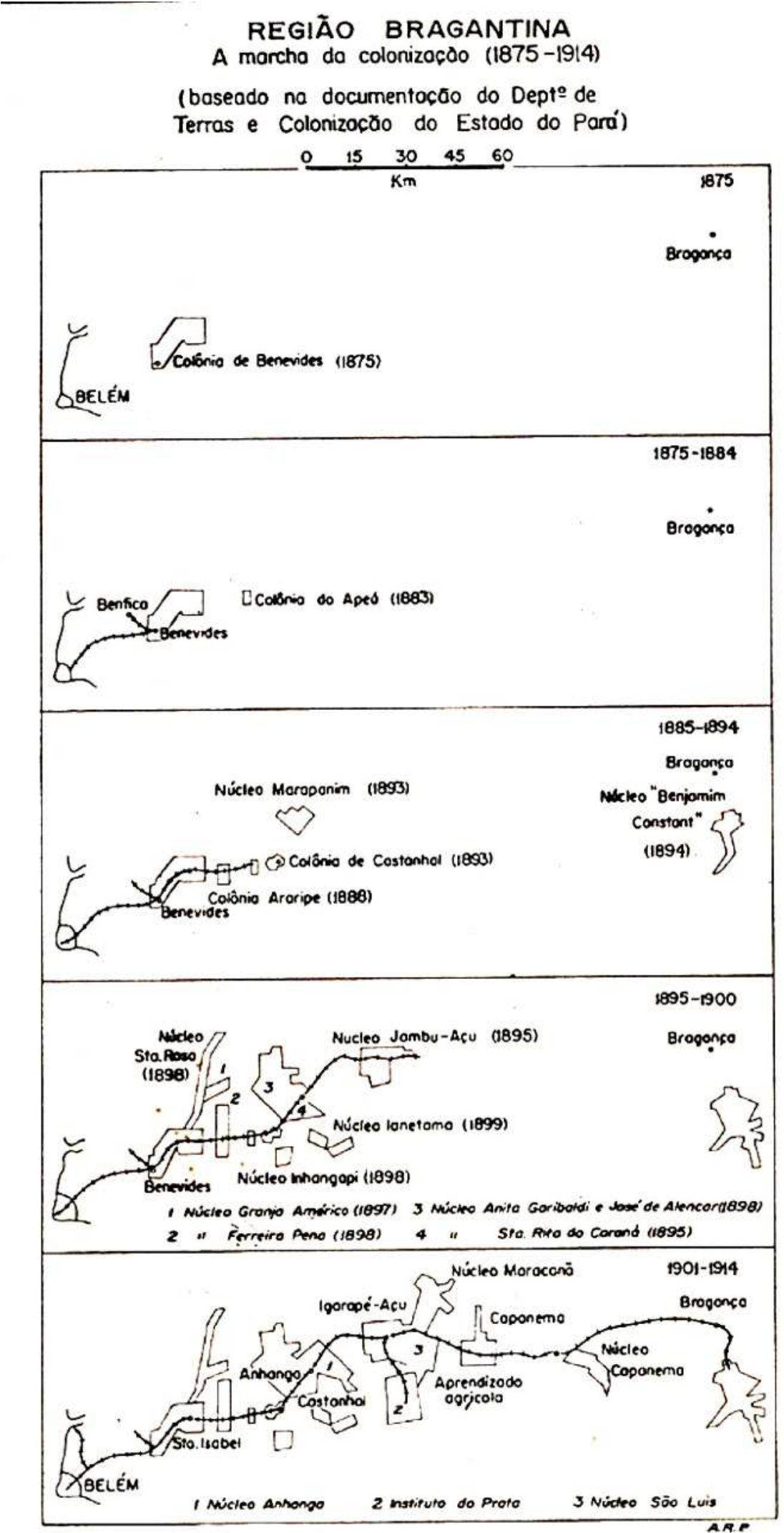

Figura 3 - Evolução dos núcleos agrícolas ao longo da ferrovia Belém-Bragança Fonte: PENTEADO (1967) 
(A)

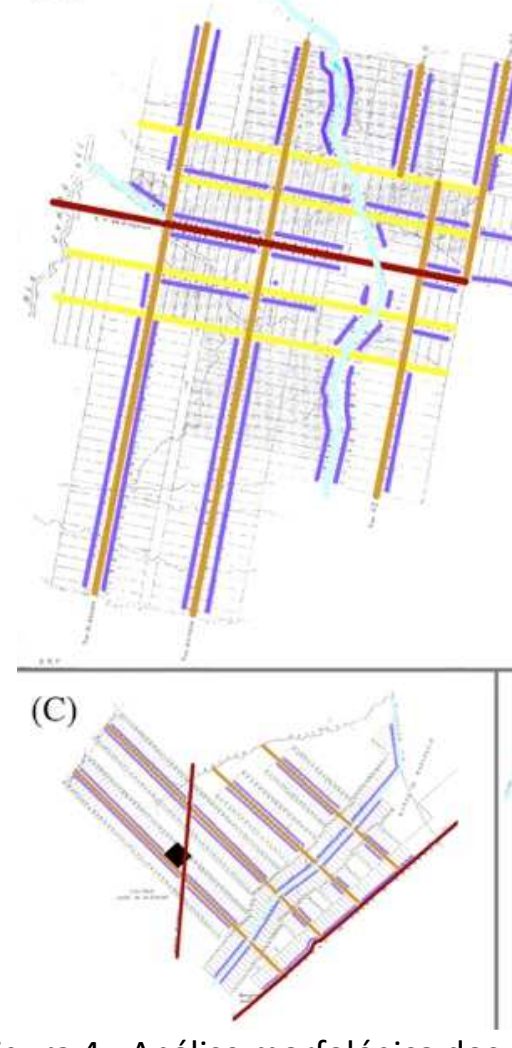

(B)

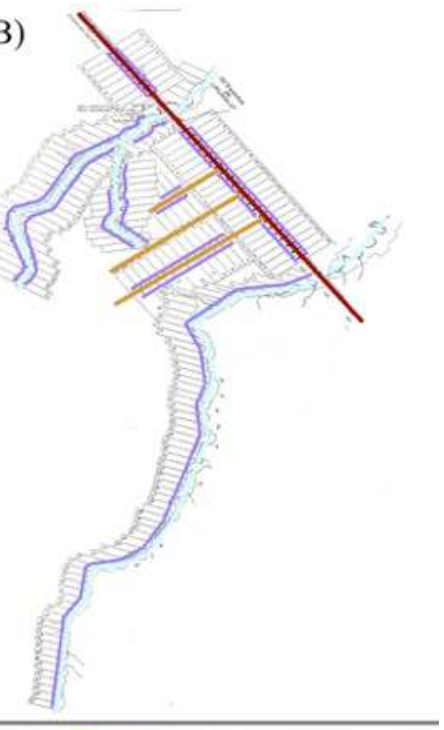

(D)

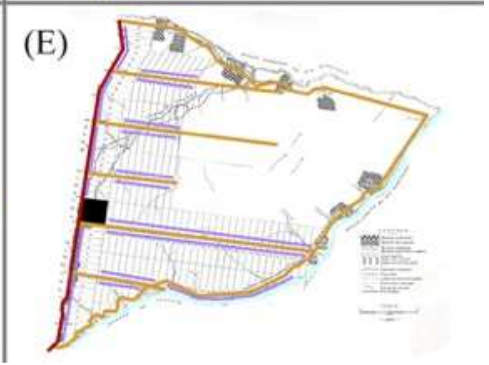

Figura 4 - Análise morfológica dos planos dos Núcleos de Colonização da Ferrovia Belém-Bragança

(A) Jambú-açú (B) Benjamin Constant (C) José de Alencar (D) lanetama (E) Anita Garibalde Fonte: Adaptado de Penteado (1967)

É possível observar em alguns planos, como os de José de Alencar, Anita Garibaldi e JambuAçú, que alguns cursos fluviais foram incorporados ao desenho do loteamento como vias de transporte com as frentes de lotes voltados para as suas margens. Apenas na planta da colônia Anita Garibaldi aparece a indicação de "terreno alagado" e nos lotes demarcados de 20 a 35 não consta o símbolo de "casa aceita" por serem justamente os lotes com frente alagada. Não se percebe nos planos, mesmo naqueles onde o traçado da sede pode ser melhor visualizado, a implantação de praças ou regulamentações quanto às fachadas e os afastamentos. O parcelamento onde as grelhas são mais proeminentes, o traçado permanece do tipo aberto, não sendo conformadas quadras efetivas, pois normalmente existia apenas uma frente de lote, como pode ser melhor observado no plano de Jambúaçu. Quanto ao uso do solo nas sedes urbanas, o únicos usos relatados eram o residencial e usos comunitários de produção (engenhos e casas de farinha).

Resumidamente, a morfologia dos planos no período da borracha consiste de um traçado viário ortogonal que valorizava o Sentido Leste-Oeste e que se apropriava dos cursos d'água 
como via de transporte interno, no entanto, a disposição dos lotes rurais não conformavam quadras, pois o parcelamento favorecia uma única frente de lote. Também não há indícios sobre a implantação de praças ou regulamentações quanto a uniformização de fachadas e afastamentos.

\section{0 rio é APP}

Cerca de 60 anos após as iniciativas de colonização da Ferrovia Belém-Bragança, o Governo Militar se utilizou de estratégia semelhante, ou seja, a colonização de um "vazio demográfico" através de uma ocupação sistematizada das margens de uma via de penetração.

Sob a égide do INCRA, a colonização realizada no Estado do Pará se caracterizou por uma organização territorial tanto em nível meso quanto micro. No nível meso, a organização ocorreu através de um planejamento integrado que previu a racionalização na abertura das vias transversais ao longo da Transamazônica, parcelamento dos lotes agrícolas em módulos de 100 hectares e a "[...] edificação de obras visando a armazenagem, a industrialização e a prestação de serviços administrativos e assistenciais" (INCRA, 1971, p. 21). No nível micro, essa organização ocorreu tanto na especificação do tipo de aproveitamento do lote quanto no estilo arquitetônico das moradias.

Como fonte para a análise morfológica utilizou-se os planos do Projeto Altamira onde a ocupação se realizou por Módulos de Colonização (MOC). O INCRA previa a implantação simultânea de duas tipologias de MOC: "O 'MOC1' foi organizado dentro do Sistema de Agrovilas, enquanto que o 'MOC2' foi contemplado com o Sistema de Núcleos Urbanos de Apoio (INCRA, 1971). A diferença mais elementar entre as duas tipologias era o local de moradia dos colonos, na alternativa 1 ou Sistema de Agrovilas, os colonos deveriam morar nos núcleos urbanos e se deslocarem para os lotes rurais; na alternativa 2 ou Sistema de Núcleos de Apoio, os colonos deveriam morar diretamente nos lotes rurais e apenas técnicos e pessoal mais especializado residiriam nos núcleos urbanos. 
O Sistema de Agrovila foi proposto pelo Arquiteto José Geraldo da Cunha Camargo e previa três tipos de núcleos urbanos: Agrovilas, Agrópolis e Rurópolis, pois para o arquiteto, a forma mais eficiente de evitar o êxodo dos colonos era fornecer na área rural a assistência técnica, médica e educacional encontrada nos centros urbanos. Era necessário, portanto, que o rurícola residisse em pequenos núcleos urbanos, integrados aos problemas do campo e que permitissem a socialização e a satisfação de necessidades básicas. Nos planos do Sistema de Agrovilas percebe-se a possível influência de teorias e utopias urbanísticas como a unidade de vizinhança de Clearance Perry, a Cidade Jardim de Ebenezer Howard e preceitos da Carta de Atenas (VENTURA FILHO, 2004; REGO, 2017; CAMARGO, 1971).

Morfologicamente os planos das Agrovila e Agrópolis possuem um padrão único ligado a um zoneamento funcional. A área central nos planos é ocupada por uma área arborizada onde funcionam diversos serviços públicos como escolas e posto de saúde, assim como equipamentos de lazer e administrativos. Na Agrovila, as quadras exclusivamente comerciais demarcam a entrada do núcleo e quadras residenciais são implantadas no entorno da praça central. Nas Agrópolis (FIG. 5), essas quadras exclusivamente comerciais são substituídas por quadras exclusivamente industriais. Duas vias principais separam um grande conjunto de diversas praças das quadras residenciais, e são introduzidas quadras de uso misto (essas quadras localizam-se nas imediações das praças, com as fachadas comerciais voltadas para as vias principais e lotes exclusivamente residenciais voltados para vias secundárias). Vias exclusivamente para pedestres ocorrem apenas nas praças principais e secundárias e nelas existem diversos bolsões de estacionamento. Todas as vias internas são largas, sendo que as vias paralelas à Rodovia medem $20 \mathrm{~m}$ com mais de 10 metros de calçada, enquanto que as vias transversais medem $15 \mathrm{~m}$ sem calçada e finalizam em um culde-sac. 


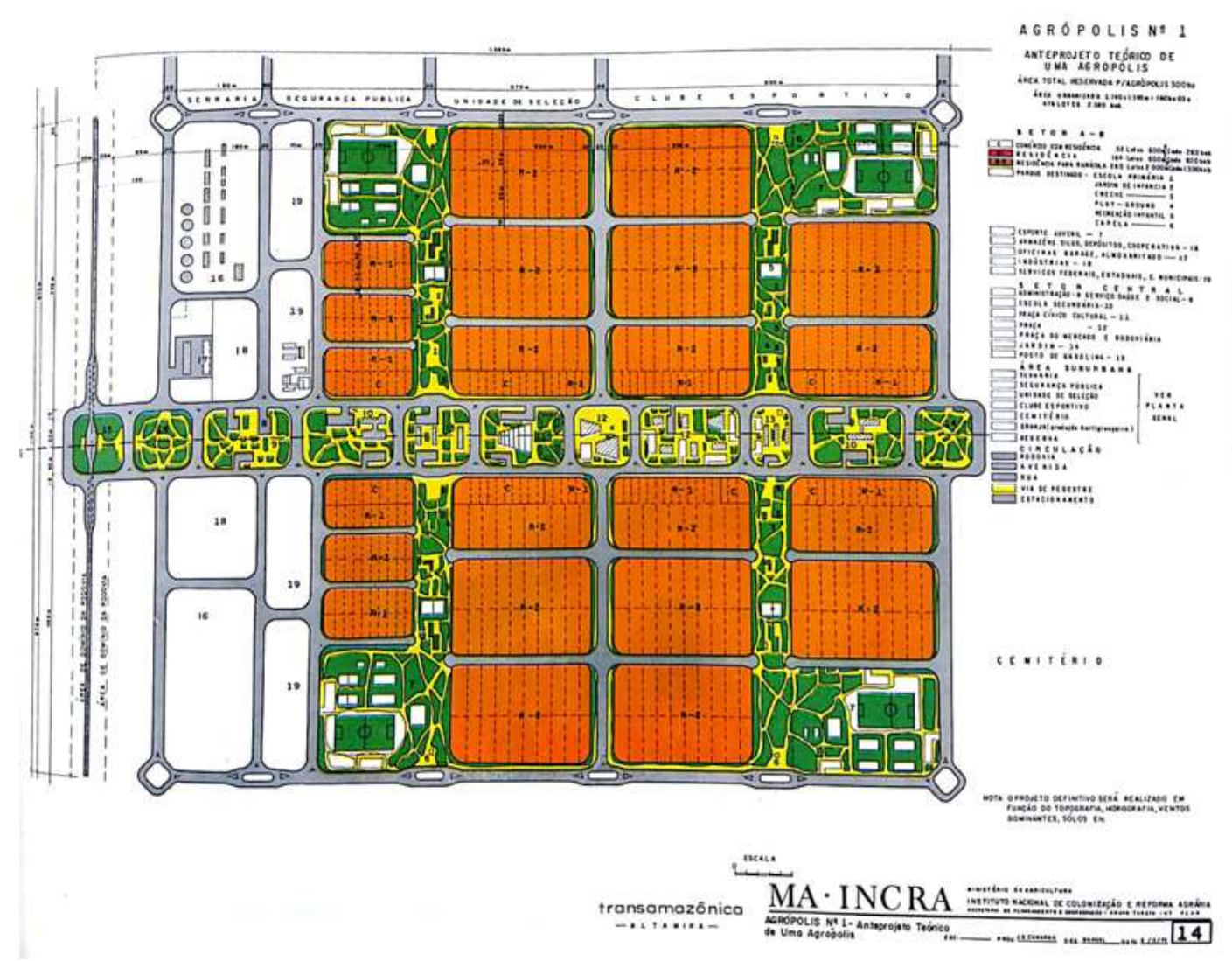

Figura 5 - Projeto de Agrópolis no MOC tipo 1

Fonte: INCRA, 1971

Já o Sistema de Núcleos de Apoio previa a existência de um núcleo principal localizado à margem da rodovia, separada desta por uma Avenida Perimetral, "ao longo da qual se alinhariam todas as construções e os equipamentos necessários ao seu funcionamento". Esse núcleo principal seria altamente zoneado com quadras exclusivamente industriais e quadras residenciais. Estas eram denominadas "Bosque Residencial Padrão", pois esperavase implantar nessas quadras uma praça central "onde se localiza a escola de 1o grau, playground, área de esporte juvenil e onde também poderão ser instaladas escolas de 20 grau, posto médico e outros equipamentos sócio-culturais que se fizerem necessários, reservando porém no mínimo 60\% de sua área para praça" (INCRA 1971, p.77). Nessas áreas residenciais as vias internas seriam exclusivamente para o tráfego a pé e a circulação de veículos de emergência como ambulâncias.

O plano de uma quadra "Bosque Residencial Padrão" (FIG. 6) é morfologicamente generoso, considerando que sua implantação seria em uma área rural. Todas as vias externas a quadra possuiriam $20 \mathrm{~m}$ de largura, no entanto, a largura das faixas de rolamento e das calçadas 
variavam entre transversais ( $14 \mathrm{~m}$ de faixa de rolamento e $3 \mathrm{~m}$ de calçada) e ruas paralelas (10 $\mathrm{m}$ de faixa de rolamento $5 \mathrm{~m}$ de calçada). Para cada via de acesso existiriam pelo menos dois bolsões de estacionamento e um acesso ao sistema de vias internas, todas sem calçada e com faixa de rolamento de $5 \mathrm{~m}$. Todas as fachadas de lotes seriam voltadas para as vias sendo que aqueles lotes voltados para as vias externas deveriam respeitar um afastamento mínimo obrigatório.

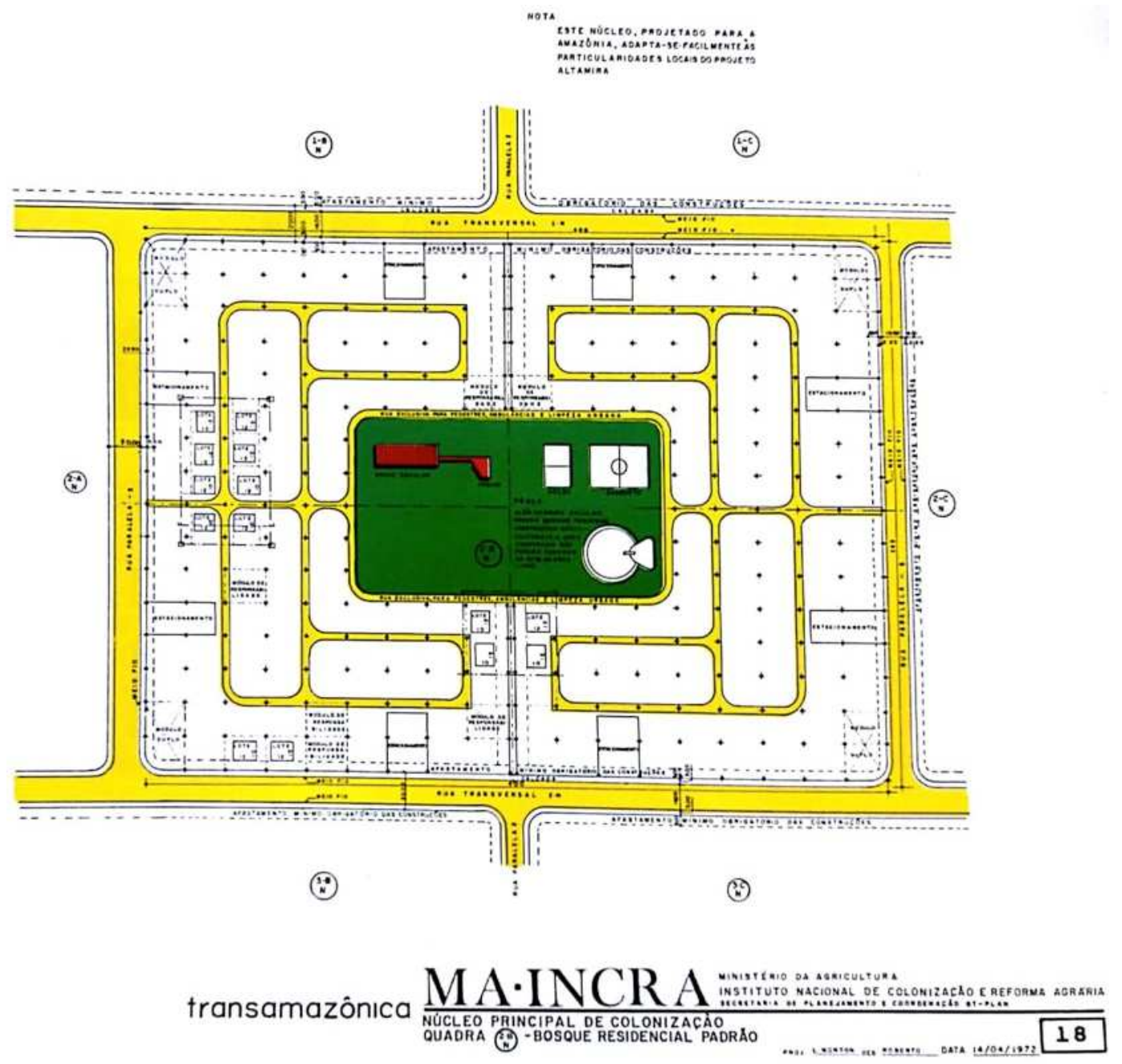

Figura 6 - Quadra Bosque Padrão do MOC tipo 2

Fonte: INCRA 1971

Os núcleos secundários desse sistema eram considerados mini núcleos onde seriam:

"(...) lotados 3 técnicos agrícolas, correspondendo a cada técnico agrícola a orientação técnica de 120 parcelas. Terá também 2 armazéns de produção, 1 armazém de consumo, 1 escola, 1 residência para os professores, outra para o vigia e uma sede e secundária com salas para os técnicos agrícolas, médico, assistente social e guarda rural". 
Em ambos os sistemas, os planos são extremamente simétricos e podem ser facilmente subdivididos em módulos internos para uma implantação em etapas. A relação entre os núcleos urbanos e os lotes rurais é relativamente idêntica para ambos os sistemas, mantendo o mesmo espaçamento entre as vicinais, o posicionamento de pelo menos um núcleo secundário/Agrovila por Vicinal. O núcleo principal ocupando o centro do $\mathrm{MOC}$, mesma determinação de $50 \%$ do lote Rural destinado à reserva florestal, formando corredores verdes nos fundos dos lotes, e propondo o mesmo tamanho para a área de expansão das vicinais e da quantidade de lotes rurais.

Entre os sistemas, no entanto, o tratamento dado aos cursos d'água é um detalhe importante. Nos planos do Sistema de Agrovilas não há menção de como rios e igarapés seriam tratados em relação ao sistema viário e à distribuição dos lotes, havendo apenas a indicação de que os desenhos deveriam respeitar as especificidades topológicas e hidrológicas. Já no plano para o Sistema de Núcleos de Apoio, um curso d'água teórico faz parte do plano (FIG. 7), e uma faixa de 30 metros em ambas as margens ao longo dele é demarcada como "non aedificandi" e nas plantas de detalhamento das quadras aparece como "margem de proteção do igarapé".

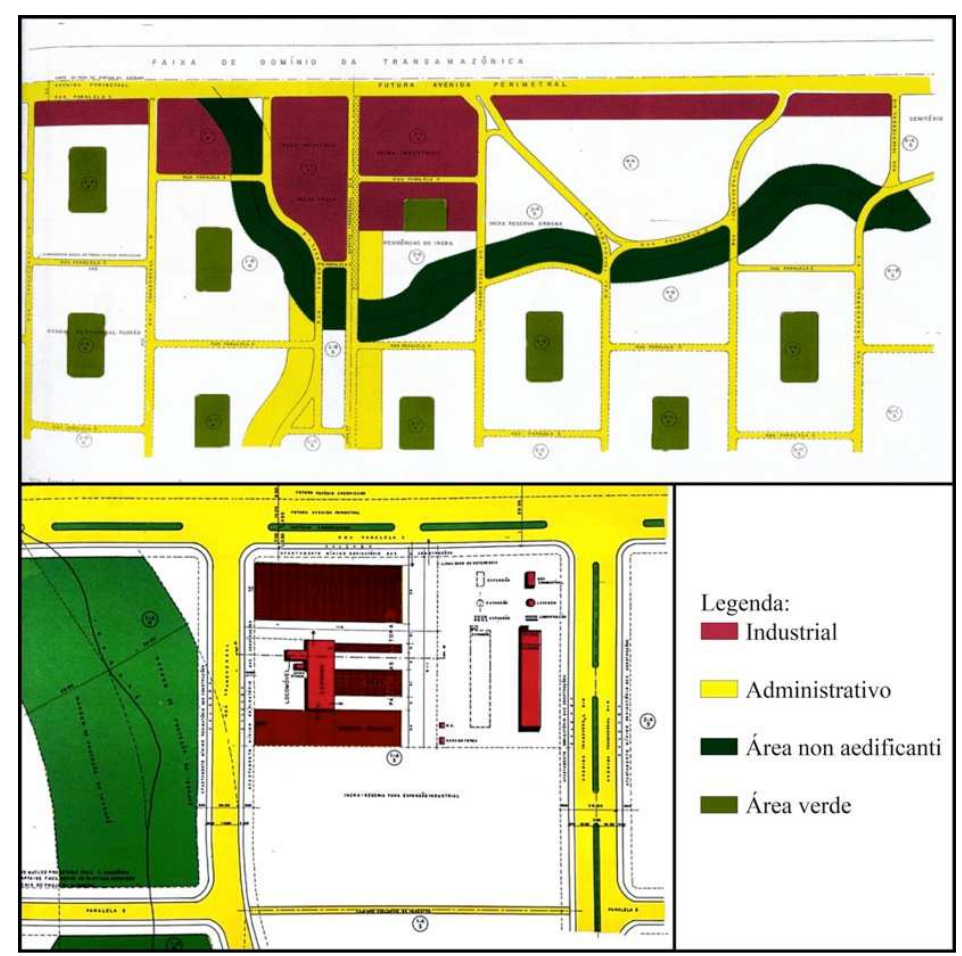

Figura 7 - Visão geral de um núcleo de apoio do MOC tipo 2 e detalhamento de uma Quadra Industrial

Fonte: INCRA, 1971 
Apesar do plano trazer a inovação de criar um corredor verde de proteção ao longo do curso d’água, a viabilidade de tal proposta é questionável uma vez que o traçado viário ignora completamente o curso do igarapé a ponto de oito vias interromperem a área de proteção sem que haja a indicação de implantação de pontes para se transpor o igarapé. Nos mapas de detalhamento se observa que não havia cuidado na proposta com a continuidade da mancha verde ou mesmo de se manter os 30m de proteção, uma vez que o código florestal vigente à época exigia para cursos d'água um mínimo de $5 \mathrm{~m}$ de APP para rios com menos de $10 \mathrm{~m}$ de largura.

Outra similaridade entre os sistemas é a uniformização das fachadas, uma vez que a construção das edificações era de responsabilidade do INCRA. As residências eram divididas em três tipologias, uma voltada para os colonos, outra voltada para os técnicos e outra ainda para os profissionais de administração (FIG. 8)
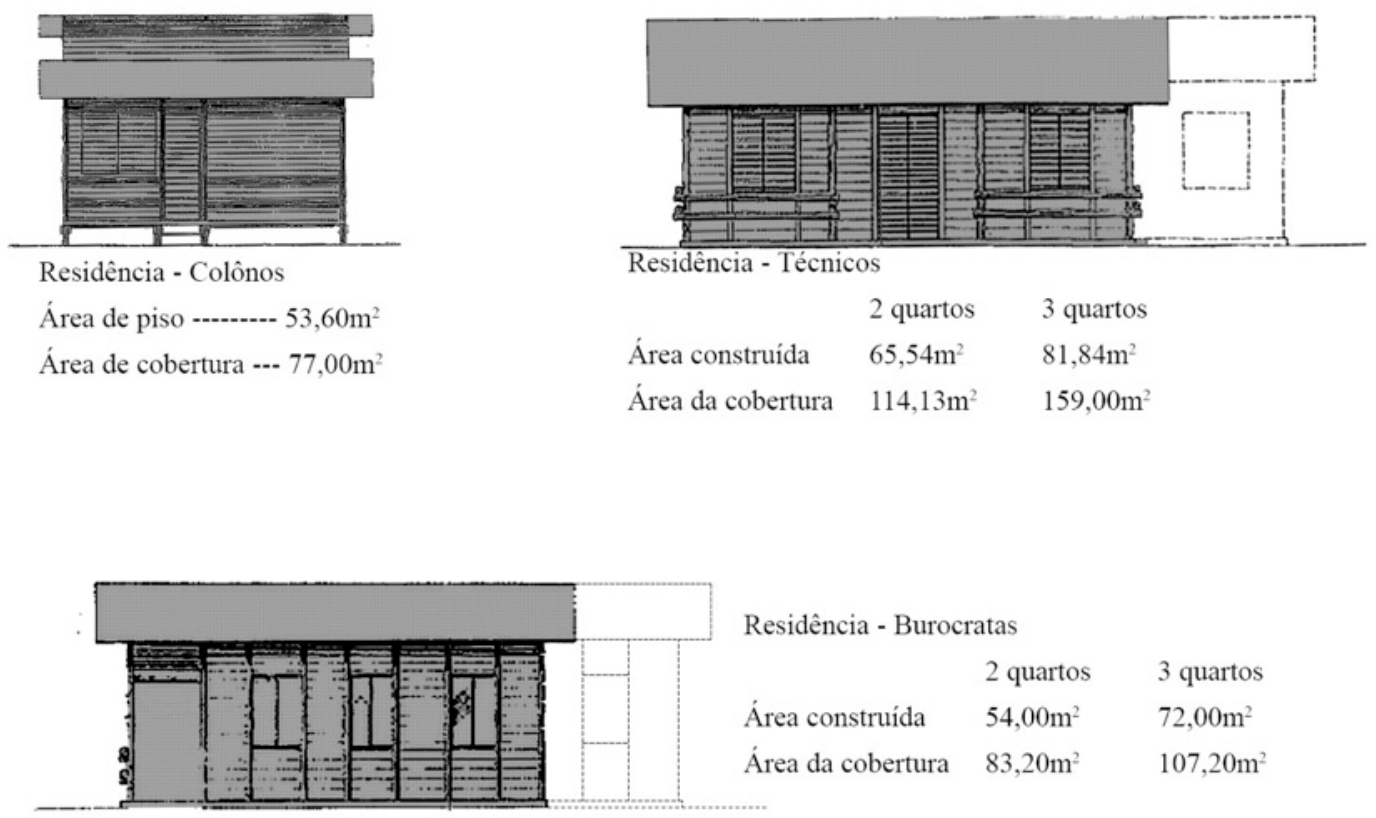

Figura 8 - Projetos de residência para os núcleos de colonização - diferenciação entre casas para colonos, técnicos e burocratas

Fonte: INCRA, 1971

Resumidamente tem-se que para o MOC1 o traçado é ortogonal articulado ao longo do eixo Norte-Sul. As praças desempenham um papel estruturante do sistema viário, e soluções para o tratamento de cursos d'água não figuram nos planos; o parcelamento das quadras 
favorece uma organização com duas frentes de lotes; ocorre uma forte homogeneização das fachadas, porém não há uma regulação mais efetiva quanto à afastamentos. Para o MOC2 o traçado é ortogonal e se organizava no sentido Leste-Oeste, no qual as praças não desempenham papel estruturante do sistema viário, elas ocorrem como ocupação do miolo da quadra com acesso exclusivamente à pé; o parcelamento dos lotes é extremamente modulado de forma a gerar diversos cul-de-sac (exclusivos para pedestres e veículos de emergência) e vinculado a regras específicas de afastamento para a construção das edificações, que por sua vez devem obedecer a uma padrão de homogeneização estipulado pelo INCRA.

\section{0 rio é Balneário}

Os últimos planos de colonização analisados foram os atuais assentamentos do INCRA. Como os planos do INCRA são individualizados para cada iniciativa de assentamento, procedeu-se ao levantamento de dados de dois assentamentos localizados no município de Moju-PA: os assentamentos Olho D'água e Boa Esperança. Estes foram criados por intervenção do INCRA para resolver conflitos agrários na área, a intermediação iniciou no fim da década de 1980 e a implantação oficial das vilas se deu na década de 1990.

As duas vilas possuem um traçado relativamente regular constituído de uma grelha de vias paralelas e transversais à Rodovia Estadual PA-150, única artéria de ligação das vilas com as sedes municipais mais próximas (Moju e Tailândia). Essas duas grelhas são também fortemente marcadas por cursos d'água. No caso da vila Olho D'água o núcleo original do assentamento é dividido ao meio por um igarapé, as duas grelhas resultantes são ligadas por uma via principal paralela à rodovia e uma área de $50 \mathrm{~m}$ sem edificações, se mostrando como uma pequena área de proteção do leito do igarapé. Nesta porção, todas as frentes de lotes se voltam para as vias internas e os fundos de lote são voltados para o igarapé. Já no caso da vila Boa Esperança, a grelha original formada por 12 transversais e duas vias paralelas a rodovia é mais regular e expandida que a de Olho D'água, possuindo uma relação menos protetiva para com um braço do Rio Ubá que atravessa o traçado viário quebrando a continuidade das vias (FIG. 9). 


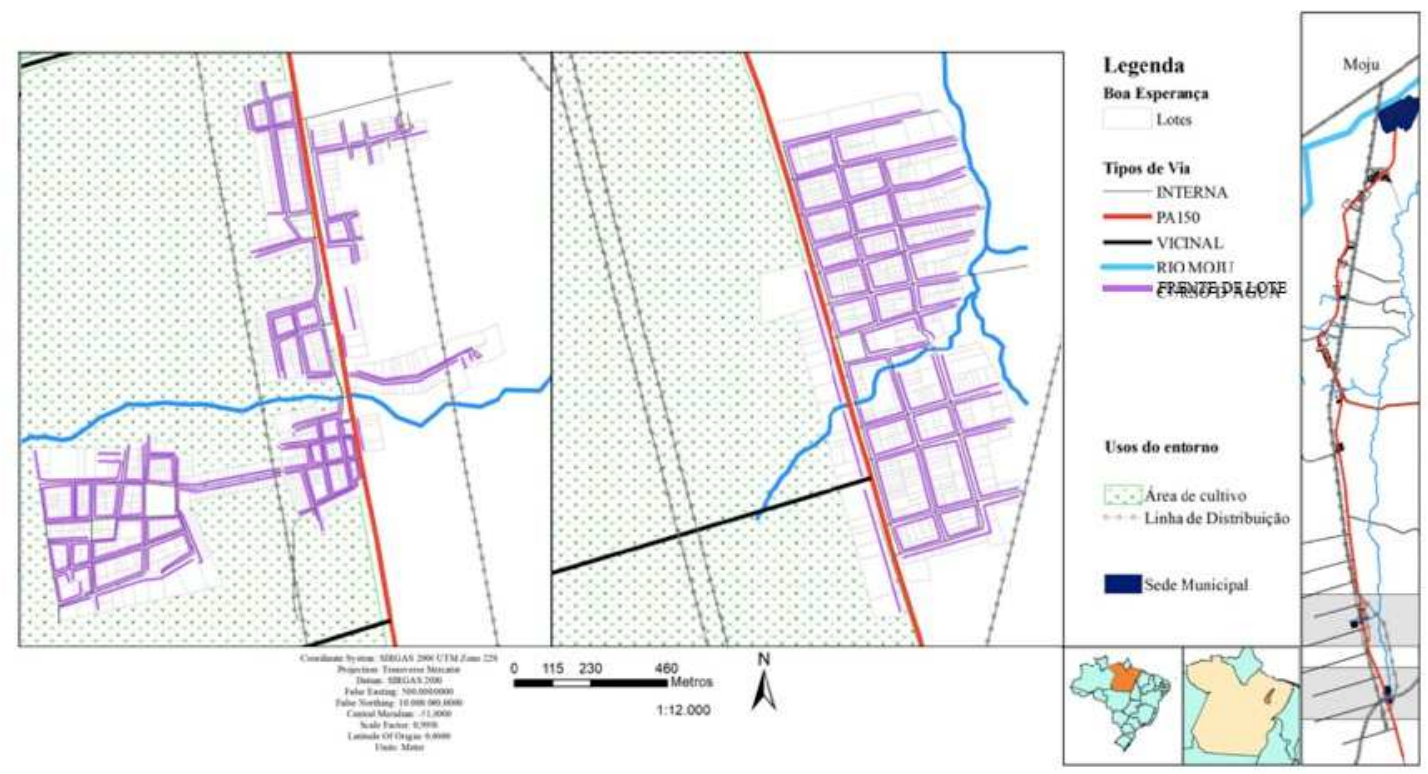

Figura 9 - Análise morfológica dos assentamentos Olho D'água e Boa Esperança Elaboração: Autor

Os cursos d'água também interferem na expansão dos tecidos dessas duas vilas, menos no caso de Olho D'água do que no caso de Boa Esperança, pois um linhão de distribuição de energia elétrica aparenta ter mais influência sobre o traçado do que o igarapé. O tecido de Olho D'água se expandiu de forma descontínua formando quatro áreas de adensamento distintas, com grelhas ortogonais irregulares e frequentemente composta de vias sem saída. No caso de Boa Esperança, a grelha se expandiu de forma mais regular com o alongamento das transversais até o encontro (e em alguns casos transposição por ponte) com o Rio Ubá e a adição de mais uma via paralela à rodovia. Esta é a única a cortar as 12 vias transversais, e seu único ponto de atrito é a ponte sobre o igarapé que no período de visita ao aglomerado estava quebrada. No caso da Vila Boa Esperança não há uma área de proteção clara perante os cursos d'água e o processo de expansão ainda não conseguiu transpor o Rio Ubá em sua totalidade. É difícil prever como o tecido da vila vai incorporar o rio, se será criada uma área de proteção ou se o rio sofrerá processos de assoreamento ou mesmo aterramento. Se estas vilas seguirem o exemplo de outras localizadas ao longo da rodovia estadual, esses cursos d'água possuem uma vocação para balneário apropriado como ponto comercial ou simples área de recreação para a população local.

Os dois assentamentos possuem praças bem definidas, no entanto, elas não se apresentam como estruturantes do sistema viário. No caso da Vila Olho D'água, sua localização - em frente a uma das escolas municipais de ensino fundamental, em um pequeno bolsão vazio 
entre a PA-150 e uma das vias paralelas - e a data de sua implantação - em 2010 - revelam o caráter residual da praça. No caso de Boa Esperança, a praça localiza-se ao lado de uma igreja católica em uma quadra diferenciada das demais, marcando o centro do assentamento. Entretanto, ainda que esteja em uma posição de relevada importância morfológica, essa praça também não possui caráter estruturante, pois é apenas um dos componentes de uma quadra de usos mistos.

Não é possível ser observado em ambos assentamentos a vigência de regras quanto a homogeneização de fachadas e a imposição de afastamentos. O parcelamento das quadras também não é homogêneo, porém é organizado de forma que existam quatro ou três frentes dependendo do posicionamento da quadra para com os cursos d'água ou mesmo na consolidação de novas áreas de expansão.

Resumidamente pode-se dizer que a morfologia dos atuais assentamentos agrários valorizam um traçado ortogonal em grelha que se articula no sentido do principal eixo de conexão (no caso específico esse eixo foi Norte-Sul); quanto aos cursos d'água existem os casos em que a população evita a ocupação de suas margens ou os incorpora na divisão dos lotes permitindo sua "comercialização"; as praças fazem parte da composição de usos, porém não são estruturantes perante o traçado viário; não há regras homogeneizadoras para a composição de fachadas ou aplicação de afastamentos; e o parcelamento das quadras valoriza uma composição com quatro frentes.

\section{A urbanidade do rio}

Sistematizando-se todas as características (FIG. 10), foi possível então identificar as permanências e rupturas de padrões morfológicos dos planos no decorrer dos séculos. 


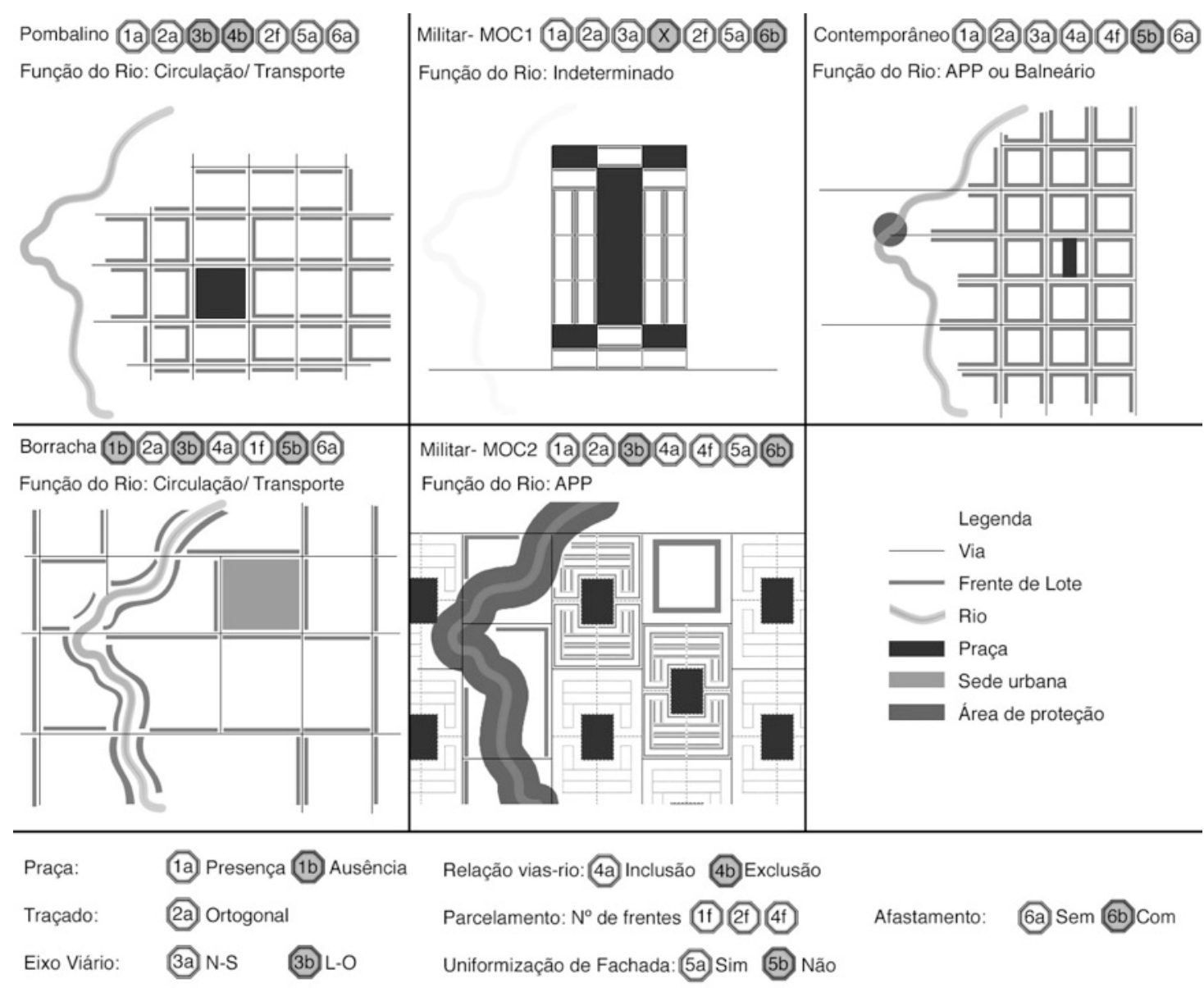

Figura 10- Sistematização das características morfológicas por período histórico Elaboração: Autores

A grelha ortogonal é uma solução viária que se manteve estável por todos os planos, refletindo sua capacidade de organização do território em parcelas acessíveis, principalmente em terra firme. Em todos os planos, as vias terrestres são as vias estruturantes, com a única exceção dos núcleos de colonização de 1890 a 1920, nos quais tentou-se introduzir as vias fluviais articuladas as vias terrestres. Os núcleos sempre eram conformados de um ponto central (as praças no período colonial; a sede urbana no período da Borracha; voltando novamente para as praças no Período Militar) a exceção desta característica está nos atuais planos de assentamento do INCRA, nos quais os pontos centrais não estão demarcados por praças mas sim por equipamentos urbanos como escolas ou posto de saúde.

As Praças aparecem também em todos os planos, com exceção dos núcleos de colonização do Período da Borracha, como estruturas marcantes do sistema viário, no entanto, sua articulação e importância variam nos planos, passando de "estruturadores" nos planos 
coloniais para "funcionais" nos MOCs do período militar. Já nos planos atuais de assentamentos rurais, as praças são propostas como "área de convivência" (relativamente residuais).

O sentido dos principais eixos viários dos traçados revela um padrão interessante. No período colonial o sentido Leste-Oeste normalmente favorecia tanto a ventilação quanto a iluminação natural e a interligação dos pontos mais importantes/dinâmicos do tecido. No período da colonização da ferrovia Belém-Bragança o sentido Leste-Oeste extrapolava o tecido do núcleo de colonização, pois vinha da própria implantação da ferrovia que ligava dois núcleos urbanos dinâmicos do território (três, se considerar o braço da ferrovia no sentido Norte-Sul que ligava Belém a Vila de Pinheiro, atual Icoaraci). Nesta mesma situação em que o eixo principal extrapola o tecido devido ao eixo viário de colonização, as tipologias de MOC do período militar se apropriam da situação de formas distintas. No Sistema de Agrovilas (MOC1) as principais vias externas estão dispostas perpendicularmente a Rodovia Transamazônica, enquanto que no Sistema de Núcleos de Apoio (MOC2) as vias principais foram organizadas de modo paralelo à Rodovia, ou seja, no MOC1 o sentido interno é individualizado em relação ao tronco de colonização, enquanto que no MOC2 o sentido é integrado ao tronco principal. Entre esses dois sistemas, o que O INCRA ainda favorece é o MOC2. Nesse sistema, as vias principais dos assentamentos se articulam de forma paralela ao tronco principal de articulação do território, ainda que o sentido do eixo viário não seja o usual: Norte-Sul ao invés de Leste-Oeste.

A relação entre o sistema viário e os cursos d'água é uma característica marcante em todos os planos de colonização. No período setecentista os rios e igarapés faziam parte do processo de consolidação do sistema viário na medida em que eles eram evitados, nunca ocorrendo frentes de lote para os rios. Já no período da borracha os cursos d'água passaram a ser integrados ao sistema viário, servindo efetivamente de via de transporte com frentes de lote voltados para eles, apesar destes lotes serem em sua maioria rejeitados pelos colonos. No Período Militar, o sistema de Agrovilas possuía planos conceituais que incentivavam a adaptação à topografia local. No entanto, sua implantação ocorreu a revelia dessa instrução, acarretando diversos problemas estruturais para os colonos como lotes sem acesso à água ou lotes inacessíveis nos períodos de chuvas mais intensas; por outro lado o Sistema de Núcleos de Apoio incorporava os cursos da água em seus planos, 
transformando-os em Área de Proteção Permanente (APP). Os atuais planos de assentamentos rurais do INCRA novamente se identificam mais com os antigos planos do Sistema de Núcleos de Apoio, pois ao cruzar com a grelha ortogonal das vilas, as margens dos rios e igarapés não são ocupadas. Há uma área de proteção que, no entanto, pode ser apropriada pela comunidade como um balneário, acarretando ou não no surgimento de um ponto comercial de entretenimento que explora o curso d'água.

O parcelamento em todos os planos revela organizações distintas de quadras e quarteirões. No período pombalino as parcelas favoreciam quarteirões com duas frentes de lote. 0 parcelamento no período da Borracha foi o mais confuso, pois os sistemas viários apesar de organizados em grelha não formavam quadras efetivas, sendo que as vias apenas serviam de acesso a um conjunto de lotes normalmente organizados em uma única frente (ou seja, em alguns casos só existiam frente de lote em um dos lados de uma via). No período militar as duas tipologias de MOC formavam quarteirões efetivos, no entanto, a quantidade de frentes variava. No MOC1 existiam duas frentes, já no MOC2 existiam quatro frentes (nas vias de acesso automobilístico) e ilhas internas com duas frentes de lote (devido às vias exclusivas para pedestres). Nos planos atuais de assentamentos do INCRA percebe-se o favorecimento da formação de quadras com quatro ou três frentes de lote, dependendo da consolidação do tecido.

O padrão de fachadas é uma característica variante, ela existiu nos períodos pombalino e militar (nos dois tipos de $\mathrm{MOC}$ ), mas não se fazia presente no período da Borracha nem nos planos atuais do INCRA. A exigência de afastamentos no padrão de fachadas existiu apenas no período militar, nos dois tipos de $\mathrm{MOC}$, não existindo deliberadamente do período pombalino, não existindo no período da Borracha pelas distâncias decorrentes do loteamento rural, e não existindo nos atuais assentamentos do INCRA pela espontaneidade de construção por parte dos colonos.

A transformação mais significativa está na função dos rios perante os planos de colonização. No período pombalino a função primordial dos rios era a circulação e o transporte de pessoas e mercadorias, essa função era externa aos núcleos de colonização, conectando as diversas vilas com a capital do Estado. No período da Borracha a função dos rios permaneceu a mesma, no entanto, passou a ser também interna aos núcleos; ao mesmo tempo em que conectava vilas, também conectava lotes rurais à sede do núcleo de 
colonização. No período militar a função dos rios muda, a circulação e o transporte das mercadorias passam a ser função primordial de rodovias federais e estaduais. Os planos do Sistema MOC1 não determinam como os rios seriam tratados, já no Sistema MOC2 os cursos d'água ganham uma função ambiental, ainda que apenas em discurso, uma vez que são tratados como área de proteção permanente. Nesse período a relação dos planos com os rios é relativamente indiferente. A inclusão dos cursos d'água nos planos é, ao mesmo tempo, uma exclusão, pois não há uma apropriação dos rios de forma mais direta, o que só passa a ocorrer no período contemporâneo dos planos de assentamento do INCRA. Como cada plano é individualizado e o INCRA realiza diversos estudos de viabilidade do assentamento, os cursos d'água passam a ser incorporados com novas configurações e funções. Nos documentos oficiais, a recomendação do INCRA é que eles sejam áreas de proteção permanente da mata ciliar, por um lado isso impacta no traçado dos núcleos e na forma como a população se apropria da área. Ao mesmo tempo que as funções de subsistência se mantêm (pesca e utilidade doméstica), outros tipos de apropriação surgem, passa-se a valorizar o quesito "amenidade", e surgem os balneários que podem ser públicos (ou seja, a comunidade se apropria em conjunto de um determinado ponto) ou privados (o proprietário de um lote transforma a margem do curso d'água em um ponto comercial).

\section{0 que aprendemos}

Percebe-se assim que as modalidades atuais de assentamentos do INCRA se apropriaram de algumas características dos planos desenvolvidos no período militar, principalmente daquelas próprias do MOC2 ou Sistema de Núcleos de Apoio, como o sentido dos eixos viários internos ser paralelo ao eixo viário regional, a grelha ortogonal formando quarteirões com 3 ou 4 frentes de lote e a presença de praças em pontos não estruturantes do traçado. No entanto, existe uma característica de remonta ao período da borracha. Foi a partir de 1890 que os projetos de colonização/ assentamento passaram a articular através de um traçado viário as grandes áreas de produção rural - com lotes rurais individualizados - a uma pequena área considerada como sede urbana. Nos planos de 1890-1900 a ênfase do 
traçado era o acesso aos lotes rurais, havendo poucos desenhos que detalhassem o traçado das sedes urbanas. Por outro lado, no período militar a ênfase se inverte, focando no detalhamento dos planos para os núcleos urbanos. O traçado ortogonal é exclusividade dessas sedes urbanas, reduzindo o acesso aos lotes rurais a um sistema de espinha de peixe, forçando os colonos a necessariamente utilizar o eixo regional e depois a vicinal no qual seu lote está localizado. Esse sistema de espinha de peixe também foi incorporado aos projetos atuais do INCRA, mantendo a necessidade dos colonos percorrerem longas distâncias para acessar seus lotes ou transportar sua produção.

Essa análise também revela um processo de evolução seguido de retrocesso quando se trata dos usos previstos pelos planos para as suas sedes urbanas. Nos primeiros projetos no período da Borracha as sedes urbanas possuíam apenas dois usos, o residencial e um de produção coletiva (engenhos e casa de farinha). A evolução ocorre no período militar com a proposta de hierarquização dos núcleos quando, dependendo do nível, os núcleos receberam diversos usos como residencial, comercial, industrial, institucional (saúde, diversos níveis educacionais, administração pública, etc.) e de lazer. O retrocesso é identificado nos projetos atuais onde os usos são limitados ao residencial, comercial, institucional (educação e saúde) e lazer.

A configuração identificada revela como os projetos atuais possuem diversos pontos potenciais para elevar a qualidade de vida da população rural assentada por esse tipo de ação governamental, como por exemplo a utilização de um traçado ortogonal também para o acesso aos lotes rurais, o que potencialmente diminuiria as distâncias percorridas; a inclusão consciente dos cursos d'água nos planos de assentamento como potenciais geradores de urbanidade (pontos comerciais ou de lazer) para aglomerados rurais, mantenedores da subsistência de famílias, como via de transporte de pessoas, mercadorias e da produção dos agricultores familiares e imprescindível recurso ambiental.

A análise realizada neste artigo é importante ao se invocar as críticas de Conzen quanto a negligência da importância dos indícios históricos, de desenvolvimento e culturais na configuração dos assentamentos humanos, uma vez que os planos de colonização do período da Borracha e do Período Militar foram as bases de ocupação que deram origem a diversos municípios do Estado do Pará. Os atuais assentamentos rurais do INCRA podem não chegar a constituírem futuras sedes de município, no entanto é possível que, 
dependendo da localização, do desenvolvimento das comunidades e de arranjos políticos locais, alguns desses assentamentos se tornem importantes centralidades municipais, como já é o caso do assentamento Olho D'água.

\section{Referências bibliográficas}

BAENA, Antonio Ladislau Monteiro. Compendio das eras da província do Para. Belém: Universidade Federal do Pará, 1969. 395p., 23cm.

CAMARGO, José Geraldo da Cunha. Urbanismo Rural para fixação condigna do Homem nas áreas agrícolas. Revista do Clube de Engenharia. Rio de Janeiro: Engenharia Editora S.A., Vol. 26, N.324 a 328, p.274-276, 1963.

CAMARGO, José Geraldo da Cunha. Urbanismo rural. Brasília: Ministério da Agricultura; INCRA, 1973.

CONZEN, M. R. G. Alnwick, Northumberland: a study in town-plan analysis. London: Institute of British Geographers, 1969.

DAOU, Ana Maria Lima. A Belle Époque amazônica. Rio de Janeiro, RJ: Jorge Zahar, 2000. 77 p., il. (Descobrindo o Brasil). Bibliografia: p.72-76. ISBN 8571105359 (broch.).

DEL RIO, Vicente. Introdução ao desenho urbano no processo de planejamento. São Paulo, SP: Pini, 1990. 198p.

DELSON, Roberta Marx. Novas vilas para o Brasil-Colônia: planejamento espacial e social no século XVIII. Tradução de Fernando de Vasconcelos Pinto. Brasília, DF: Centro Integrado de Ordenamento Territorial: Alva, 1997. 124 p., il. ISBN 8586774022 (broch.).

FLEXOR, Maria Helena Ochi. Vilas Pombalinas na Região Amazônica. In: Seminário de História da Cidade e do Urbanismo, 11., 2010, Vitória. Anais... . Vitória: Shcu 1990, 2010. v. 11, p. 1 - 12. Disponível em: <http://unuhospedagem.com.br/revista/rbeur/index.php/shcu/article/view/1335/1309>. Acesso em: 26 jan. 2017.

INCRA - Instituto Nacional de Colonização e Reforma Agrária (Brasil). Assentamentos. Disponível em: <http://www.incra.gov.br/assentamento $>$. Acesso em: 13 maio 2018.

INCRA - Instituto Nacional de Colonização e Reforma Agrária (Brasil). A Colonização no Brasil: situação atual, projeções e tendências. [Brasília]: O Instituto, 1971. 32p., mapas.

INCRA - Instituto Nacional de Colonização e Reforma Agrária (Brasil). Projeto integrado de colonização Altamira - 1. [Brasília]: INCRA, [1972] 219 p. :

OLIVEIRA, Vitor; MONTEIRO, Cláudia. Perspectivas: As origens da morfologia urbana e a geografia alemã. Revista de Morfologia Urbana, Porto, v. 1, n. 2, p.37-40, 2014. Disponível em: http://pnum.fe.up.pt/pt/files/5114/0180/2180/RMU 2.1 Perspectivas.pdf. Acesso em: 23 set. 2016.

PENTEAdO, Antônio Rocha. Problemas de Colonização e de uso da terra na Região Bragantina do Estado do Pará. Belém. Ed. Da UFPA, 1967. 2 v. (Coleção Amazônia. Série José Veríssimo)

REGO, Renato Leão. Shaping an urban Amazonia: 'a planner's nightmare'. Planning Perspectives, [s.I.], v. 32, n. 2, p.249-270, mar. 2017. Informa UK Limited. http://dx.doi.org/10.1080/02665433.2016.1277952. Disponível em: <http://www.tandfonline.com/doi/abs/10.1080/02665433.2016.1277952>. Acesso em: 11 out. 2017.

SAMUELS, Ivor. Consents last bolt: Reflections on 'Thinking about Urban Form'. Urban Morphology, [s.I.], v. 9, n. 2, p.136-144, out. 2005. Disponível em: http://www.urbanform.org/online_unlimited/pdf2005/200592_136144.pdf. Acesso em: 29 ago. 2016.

TEIXEIRA, Manuel C.. A forma da cidade de origem portuguesa. São Paulo: Editora Unesp Imprensa Oficial do Estado de São Paulo, 2012. 208 p. 
VENTURA FILHO, Raul da Silva. A Floresta Urbanizada: a formação de núcleos urbanos na transamazônica, trecho Altamira - Itaituba. 2004. 239 f. Tese (Doutorado) - Curso de Pós-graduação em Planejamento Urbano e Regional, Instituto de Pesquisa e Planejamento Urbano e Regional, Universidade Federal do Rio de Janeiro, Belém, 2004.

WEINSTEIN, Barbara. A borracha na Amazônia: expansão e decadência 1850-1920. São Paulo, SP: Hucitec: USP, 1993. $371 \mathrm{p}$.

WHITEHAND, Jeremy W. R. Morfologia urbana Britânica: a tradição Conzeniana. Revista de Morfologia Urbana, Porto, v. 1, n. 1, p.45-52, 2013. Disponível em: http://pnum.fe.up.pt/pt/files/1913/8418/5713/Whitehand 2013.pdf. Acesso em: 23 set. 2016. 